LOCAL WISDOM, 13 (1): $100-111,2021$
Local Wisdom Scientific Online Journal
ISSN: 2086-3764

\title{
Conservation of Natural Resource Management in the Buffer Village Community of Alas Purwo Banyuwangi National Park East Java Indonesia Based on Local Wisdom
}

\author{
Eko Setiawan $^{1^{*}}$, Keppi Sukesi ${ }^{2}$, Kliwon Hidayat ${ }^{3}$, Yayuk Yuliati ${ }^{4}$ \\ ${ }^{1 *}$ Graduate Student of Sociology, Faculty of Agriculture University of Brawijaya, Indonesia \\ 2,3,4Department of Agriculture, University of Brawijaya, Indonesia \\ Corresponding Author: oke.setia@gmail.com
}

\section{Keywords: \\ Alas Purwo; National \\ Park; Conservation; \\ LocalWisdom.}

\section{Abstract}

This research describes the life of the people around the buffer village area of Alas Purwo National Park which has local wisdom in the form of a number of traditions, in the form of rules or restrictions that are still valid for generations. This local wisdom has the value of ecological intelligence that is maintained and developed so as not to be driven by modernization. Local wisdom owned by the community is used as a reference in the management of forest areas, both myths, abstinence. The type of research used is descriptive qualitative with sociological approach with case study design. The results showed that the community around Alas Purwo National Park area has local wisdom in the form of a number of traditions, rules or restrictions that are still valid for generations that are then maintained and obeyed until now. The restriction is in the form of a ban on killing peacocks and menco and abstinence in the payang system.

Article History Received

Accepted

Published

\author{
: Dec 3, 2020 \\ Jan 6, 2021 \\ : January 15, 2021
}

\section{INTRODUCTION}

Indonesia is still ranked second in the world in terms of biodiversity wealth, after Brazil covers $10 \%$ of flowering plant species, $12 \%$ of mammals, $16 \%$ of reptiles and amphibians, $17 \%$ of birds and $25 \%$ of fish species found in the world. Abundance and the large number of plants and wildlife in Indonesia, placing Indonesia as the country with the third highest level of diversity in the world (Director General of KSDAE, 2016). The Government of Indonesia has established a conservation area of 521 units, an area of approximately 27.1 million hectares to protect biodiversity wealth (Directorate General of Layoffs, 2014). One of them is the natural wealth that must be preserved as a balance of nature and the lungs of the earth, because in forest ecosystems there are various biodiversity and nonbiological. Forest is a very potential area in the socioeconomic life of people living in the area around the forest. Village communities around forests or so-called traditional communities are inseparable because they are part of the forest ecosystem (Magdalena, 2013).

Kalipait village is the clearest portrait of how unique the ability to adapt the social structure of the community. People's lives are still on magersari land, and have a key 


\section{Conservation of Natural Resource Management in the Buffer Village Community of Alas Purwo Banyuwangi National Park East Java Indonesia Based on Local Wisdom \\ Eko Setiawan, Keppi Sukesi, Kliwon Hidayat, Yayuk Yuliati}

position in forest management. While Kutorejo Hamlet is a hamlet that is directly adjacent to the Alas Purwo National Park area, so doing various activities and relying heavily on national parks is very high. Every day they have to go in and out of the forest of Alas Purwo National Park, in search of forest products and marine biota. Villagers, the majority of their livelihoods depend on the forest, namely as timber seekers and as fishermen. Forests are not only a source of fulfillment of life's needs, but have social, cultural and religiosity functions. Because the forest with the community around the national park area there is a very close bond that has been going on since hundreds of years ago. The community around the national park has local wisdom values that are formed from repeated interactions between communities and forest resources. As a result, a system of socio-cultural order of the community is developed that is integrated with the forest ecosystem. Forests become a unified cultural environment to be the focus of people's lives around the national park area to support their life system (Munggoro, 1999).

Various activities of people in the forest at that time continued to approach the area that is currently called the core zone, where they used to establish temporary settlements resting places to search for forest products and marine biota. In fact, challenges in forest protection and management in Indonesia often come from local communities around the forest. Magdalena (2013) stated that the sustainability of forest management depends heavily on the participation of local communities in management. The relationship between forests and local communities is inseparable from the concept of ecosystems, an ecological system formed by the reciprocal relationship between living things and their environment (Soemarwoto, 2014). Gauthama, et al (2013) stated that javanese people implement the nature of human relationship with nature with philosophy memayu hayuning bawana (trying to keep the world safe and all its contents in order to be maintained and harmonious). This public perception can be used as a moral guide and pranata in regulating human relationships with the use of forest natural resources in a responsible and sustainable manner.

Actually community interaction with forests with local wisdom has been going on for a long time before the determination of forest areas into conservation areas. Local wisdom that can support conservation is formed from the interaction between humans and their environment so that traditional people have a deeper understanding of their environment (Beltran \& Phillips, 2010). Local wisdom shows that there is an inseparable relationship between typical human behavior and its environment, namely forming human behavior collectively in the form of norms that must be adhered to through generations. In line with Liliweri's expression (2014), that local wisdom can be interpreted as a view of life that develops in a particular social and ethnic community that is limited by elements of regional, geographical, and unique historical experiences. The knowledge system becomes typical of a place and oriented to natural language is often referred to as local wisdom (Widiana \& Wikantiyoso, 2018).

Efforts to study the interconnectedness of community interactions have actually been carried out, but still have not provided comprehensive results. Van Assendelf (1991) has conducted research on human impacts on the Alas Purwo National Park area, but this study only describes various human activities along the coastline, not specifically identifying the influence of human activity. A more complicated study on human interaction with national park areas has actually been done by Pramusanti (2001) but only limited to interacting with the community in the collection of natural resources. Some cases of failure in conservation occurred as stated by Iswandono (2016) in this study there is no meeting point in the joint management between forest area managers and traditional 
communities in conducting forest conservation, therefore forest management should integrate local wisdom with conservation principles. Local wisdom that supports biodiversity conservation has the same goal, namely the realization of biodiversity sustainability for the welfare of the community, but traditional knowledge is poorly understood because it is considered ancient and unreasonable (Kosmaryandi, 2012).

The urgency of assessment of participation in participation activities in conservation activities that are top down is proven to give maximum results. Mendez-Lopez (2014) conducted research in Mexico also acknowledged that low community participation in conservation activities is due to the many conditions of the community that have not been fully examined. Similarly, Thaman's findings (2016) prove that the participation of rural communities in conservation activities in Portugal is only $43 \%$, making conservation ineffective. Unlike in Fiji, the buttom up approach shows $88 \%$ greater community engagement, making conservation activities effective. The effect of community participation on conservation success can also be seen in Costa Rica, when the community participates then the private sector is involved (Aguilar-Stoen, 2015). This condition gives the meaning of activities that use a participatory approach and togetherness will give good results.

From the description above, it can be seen that with the heterogeneity of existing society causes the emergence of variations in social and cultural behavior in society towards the environment. With the uniqueness, cultural diversity, environmental relations and traditional communities in the Alas Purwo National Park area, making uniqueness and attractiveness to be researched in accordance with the problems of this modern age, as has been done by previous researchers who are still related to humans and their environment. Novelty this research is finding a way to do biodiversity conservation by integrating the local wisdom of the community around the Alas Purwo National Park area.

There have been many studies that integrate local wisdom and conservation with different research focuses, including: focus on zoning (Freitas \& Tagliani 2009, Kosmaryandi, 2012), while differences, methods and processes of integration of national parks (Bohensky \& Maru, 2011), traditional ecological knowledge of species populations (Fraser et al. 2006; Gagnon \& Berteaux 2009; Moller et al, 2004). Classification of vegetation and environment (Naidoo \& Hill 2006). This research is expected to provide benefits for stakeholders, as well as support to national park managers to engage traditional communities around buffer villages by integrating local wisdom into conservation activities.

\section{LITERATURE REVIEW}

Alas Purwo National Park as legally mandated conservation objectives are contained in the Law of the Republic of Indonesia Number 5 of 1990 concerning the Conservation of Biological Natural Resources and Their Ecosystems aimed at the realization of the sustainability of biological natural resources and the balance of their ecosystems so as to further support efforts to improve the welfare of the community and the quality of human life. It has three main functions, namely: protection of ecological processes of life buffer system, preserving the diversity of plants and animals and their ecosystems, sustainable utilization of biological natural resources and their ecosystems in the form of research, science, education, supporting cultivation, natural tourism, and recreation. National Park is one of the conservation areas that contains aspects of preservation and utilization so that this area can be utilized for ecotourism development, supporting cultivation (Arief, 2015). (Mangunjaya et al, 2017) states that conservation to form an ideal environment, where between humans and other creatures are in desperate need. 


\section{Conservation of Natural Resource Management in the Buffer Village Community of Alas Purwo Banyuwangi National Park East Java Indonesia Based on Local Wisdom \\ Eko Setiawan, Keppi Sukesi, Kliwon Hidayat, Yayuk Yuliati}

The history of Indonesia as a place in a long cultural landscape then called Nusantara is a Locality. Nusantara spread from sabang to merauke has a wealth of local wisdom value which is a diversity (Teng, 2017). Local people around alas purwo national park area, generally apply local wisdom. Local wisdom is the main thing for the community in adapting to nature and become a cultural heritage contained in the concept of thinking of local people (Nurdin \& Ng, 2013). (Ayatrohaedi, 2016) states that local wisdom is formed as a cultural advantage of local people as well as geographical conditions in a broad sense. Local wisdom consists of two words, namely wisdom while local indicates the interaction space where the event or situation occurs (Wikantoyoso, 2019).

Environmental management through local wisdom is considered to play an important role, because it refers more to the practices, knowledge, values and beliefs of individuals in developing an environment historically, conception and perception by local people (Richeri et al., 2013). The need to integrate local wisdom and conservation efforts of natural resources because it is a manifestation of the concept of thinking about the environment, so that it becomes the capital of understanding on the quality of biological resources in a sustainable manner (Henri, Hakim, \& Batoro, 2018). The balance of the environment needs to be maintained with high awareness by the local community, in its own way in accordance with the mindset and traditions that took place in its time has been able to create ways to preserve the balance of the environment (Triastianti, Nasirudin, Sukirno, \& Warsiyah, 2018). Thanks to local wisdom they can carry on their lives, even be able to develop sustainably (Permana, 2010). More precisely this local wisdom is called the traditions that exist in the community where every action or action that is usually carried out is in accordance with the rules that exist in the community itself (Francis, 2015). However, local wisdom in various regions has similar functions as guidelines, signs as controllers to behave and interact with nature (fauzi, 2013). (Yamami, 2011) expresses local wisdom in the form of knowledge, norms, ideas, values, skills, experiences, behaviors, habits, regulations in a region to meet the needs of living together passed down through generations.

Local wisdom that survives until now as a prohibited forest turns out to have a lot of positive value in nature conservation and forest protection, it can be imagined what would happen if Alas Purwo National Park without the legitimacy of the national park by relying only on the national park zoning system. Local wisdom is a social capital developed by the community to create a balance between the socio-cultural life of the community and the sustainability of natural resources.

\section{RESEARCH METHODS}

This research uses the paradigm of constructivism as a philosophical basis to understand the reality in the community around the buffer village of Alas Purwo National Park. The paradigm of constructivism is normative, showing its practitioners what to do without the need for long existential or epitemological considerations (Mulyana, 2003). The method used in this research is a sociological approach with case study design. Qualitative research emphasizes processes and meanings that are not rigorously tested or measured in terms of quantity or frequency (Denzin\&amp;Lincoln, 2000). Informants are defined by purposive techniques. Data collection using observation and in-depth interviews. In-depth interviews were conducted using several competent informants in providing information (Primadesi, 2010). Interviews addressed to informants are conducted separately with other informants aimed at avoiding the direct influence of the informant's previous opinions (Da Cunha \& De Albuquerque, 2006). 
This research focuses on data mining related to local community interaction around Alas Purwo National Park area, as well as extracting information about compliance or prevailing values and norms in local communities related to aspects of local wisdom that are behind the behavior of residents. The data obtained was then continued in the form of FGD (Focus Group Discussion) discussion, the aim was to obtain information and input to researchers on specific matters (Wong, 2008). The FGD in this study used two designs: 1) forming a small group of hypothetical results and initial analysis before being developed more structured and systematic, 2) forming large groups as a follow-up to the initial discussion, to find the expected results to add to the research information (Wilkinson, 1998). Thus, harmonization of communication and interaction can be achieved to the maximum (Neuman, 2003). Data analysis using interactive models, including components, data collection, data reduction, data feed, inference.This research uses data analysis techniques model Milles and Huberman. Data analysis techniques are carried out interactively and take place continuously until complete until the data is saturated. The activities in data analysis can be explained as follows.

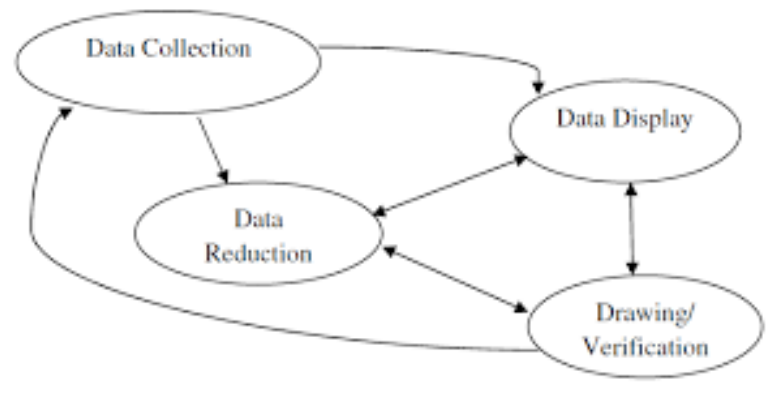

Figure 1. The activities in data analysis

\section{RESULTS AND DISCUSSIONS}

\section{The Existence of the Community Around Buffer Village}

Kalipait village is the clearest portrait of how unique the ability to adapt the social structure of the community. People live in buffer villages, and have a key position in forest management. While Kutorejo Hamlet is a hamlet that is directly adjacent to the Alas Purwo National Park area, so doing various activities and relying heavily on national parks is very high. Every day they have to go in and out of the forest of Alas Purwo National Park, in search of forest products and marine biota. Villagers, the majority of their livelihoods depend on the forest, namely as timber seekers and fishermen. Forests are not only a source of fulfillment of life's needs, but have social, cultural and religiosity functions. Because the forest with the community around the national park area there is a very close bond that has been going on since hundreds of years ago. The community around the national park has local wisdom values that are formed from repeated interactions between communities and forest resources. As a result, a system of socio-cultural order of the community is developed that is integrated with the forest ecosystem. Forests become a unified cultural environment to be the focus of people's lives around the national park area to support their life system.

The community around Alas Purwo National Park has local wisdom in the form of a number of traditions, in the form of rules or restrictions that are still valid for generations that are then maintained and obeyed by the community. This local wisdom has the value of ecological intelligence that needs to be maintained and developed so as not to be tempted by modernization. Local wisdom owned by the community is used as a reference in the management of forest areas, myths, religious ritual practices. They consider that the forest 


\section{Conservation of Natural Resource Management in the Buffer Village Community of Alas Purwo Banyuwangi National Park East Java Indonesia Based on Local Wisdom Eko Setiawan, Keppi Sukesi, Kliwon Hidayat, Yayuk Yuliati}

is a gift from God or a gift from God that is sacred and sacred. They think that the gift must be maintained so that it does not perish, or be over-exploited. In addition, they also believe that the forest has magical powers, and supported by myths inherited from the time of ancestors. The surrounding community through mythical concepts, ritual practices, forest management, they try to always maintain the relationship between their natural environment in order to remain harmonious. Local people in general are very well acquainted with the surrounding environment. They live in a variety of natural ecosystems, and have long coexisted with nature harmoniously so that they know various ways of utilizing natural resources in a sustainable manner. Local wisdom owned by the villagers then has implications both for the environment and for the lives of the people around the national park area. Forest management activities in the national park area, with the presence of local wisdom has a positive impact on the preservation of plants to maintain the balance of ecosystems.

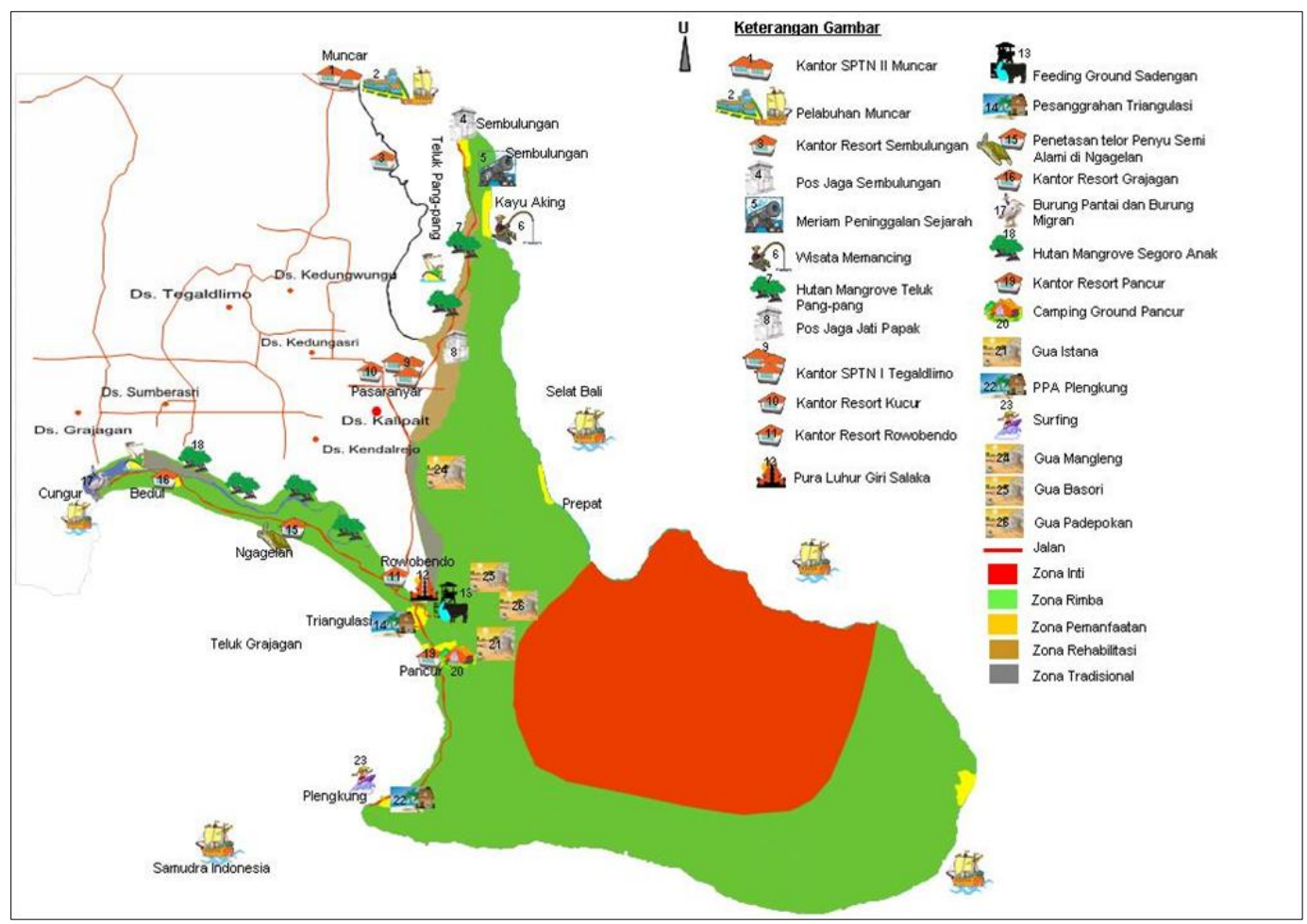

Figure 2. Research Location Map

\section{Prohibition of Killing Peacocks and Menco}

In fact, the traditional communities around Alas Purwo National Park have ways in conservation efforts. Local wisdom owned by the community around the national park area, turns out to have conservation value in maintaining natural sustainability that is still used in daily life. Local wisdom in utilizing natural resources, until now still carried out and believed through generations. The purpose and purpose in the form of symbols or signs can be in the form of prohibitions, such as abstinence from taking menco birds and killing peacocks. The prohibition on taking menco and killing peacocks, the abstinence according to the community because it is caused because peacocks and menco birds are the favorite animals of the spirits of alas purwo national park. Currently it is still obeyed by the community around the national park area, because the existing conservation values of the community indirectly make efforts to preserve biodiversity. 
Especially for two peacocks and menco animals are one component of the ecosystem, so that with the preserved animals, the quality of the ecosystem can be indirectly maintained. The community around the national park area also develops an adaptation of living with animals. One of them is a form of local wisdom seen from the call of respect to elephant animals and tigers with the title simbah, eyang, grandma. Elephants are called as big simbah, tigers with the name of loreng simbah. Conservation values are to reduce activities within the buffer zone, resulting in the utilization of natural resources can be minimized.

\section{Abstinence in the Payang System}

The payang system includes fishing equipment or shrimp that has long been known to Indonesian fishermen. Payang is a bag trawler used to catch hordes of surface fish (Brandt, 1995). On the lower part of the wings and mouth of the net are given ballast, while the upper part is given a buoy. Usually the largest buoy is placed in the middle of the mouth of the net, on both front ends of the wings connected with a long rope is commonly called a diving rope. Wings are sheets of nets that are put together and serve as a herd for fish, so that the fish leads to the mouth of the net. The wings consist of left and right wings and have a large net eye size from the other parts. Ris rope itself there are two parts, namely the upper and lower ris rope, the upper ris rope is longer than the lower ris rope so that the upper part of the net lip is more jutting in. Ris rope serves to stretch the net that is the place of buoys (floats) and ballast (sinker). A sheet rope is a rope that binds the end of the right and left wings of the net, serves to connect between the net and the boat. Buoys and ballast serve to help the mouth opening of the net, in addition serves to maintain the shape of the net remains stable and keep the mouth opening of the net from the influence of wind and current when operated. Ballast serves to make the bottom of the net well submerged so that it forms a maximum opening of the mouth of the net (Boesono, 2014).

Fishing using brackish nets can be done both at night and during the day. For catching done during the day using rumpon aids or just by guessing in a place that is thought to be a lot of fish. Usually in April, May, June, fishermen often use fishing gear with light aids and arrests are made at night. Meanwhile, if it has entered September, October, the fishermen use rumpon aids and arrests are made in the morning until the afternoon (Amry, Renta, \& Nofridiansyah, 2017). The rumpons are very simple and still made in the traditional way. The material of this rumpon consists of dried coconut leaves, twigs, used tires, slap ropes and large stones that serve as ballast. Rumpon is a form of local wisdom that provides education on environmental conservation, which provides a place to be a home for fish and not to damage the environment. Even if studied more thoroughly will have a positive impact on the environment, namely with the presence of this rumpon then as a home for fish as a shelter from predators, besides that there is a food chain as a form of natural balance will occur around rumpon. This alone as a form of concern of the fishing community to the environment, with the implementation of local wisdom rumpon, it is expected that the future can be developed with better technology, in the form of artificial coral reef development.

Fishermen in Plengkung Beach know three fishing seasons, namely the spring, medium and peak seasons. In the season the catch rate is very low, the time of the season is medium, while the peak season time of the catch is high. The implementation system of fishing using the payang method, carried out on five days before the full moon until five days after the full moon because at that time there was a high tide that caused fish and shrimp carried away by currents to fall into the estuary. This system can only be implemented around the full moon, while on other days it cannot be done. Implementation of the payang system, there are some restrictions not to do other activities such as rationing. 


\section{Conservation of Natural Resource Management in the Buffer Village Community of Alas Purwo Banyuwangi National Park East Java Indonesia Based on Local Wisdom Eko Setiawan, Keppi Sukesi, Kliwon Hidayat, Yayuk Yuliati}

Based on the belief if it violates the abstinence then the results obtained will be few. Conservation values contained in the payang system, the utilization of natural resources using simple and environmentally friendly equipment can reduce ecosystem damage. The existence of some restrictions during the payang by using other tools to take natural resources, there is a moral education that the perpetrators are invited to be wise in taking natural resources as necessary is not excessive.

\section{CONCLUSION}

Alas Purwo National Park has the potential because in its management it still applies local wisdom. The community around Alas Purwo National Park has local wisdom in the form of a number of traditions, rules or restrictions that are still valid for generations that are then maintained and obeyed by the community. The life of the buffer village community is very closely related to conservation efforts. This can be seen from the form of local wisdom, such as:

prohibition on taking or killing menco and peacocks. The abstinence is according to the belief of the public that peacocks and birds are the favorite animals of the spirits of alas purwo national park. Currently, it is still adhered to by the communities around the national park area, because the existing conservation values of the community are indirectly an effort to preserve biodiversity. Especially the two peacocks and menco birds are one component of the ecosystem, so that with the preserved animals the quality and quality of the ecosystem can be indirectly maintained intact.

The payang system includes fishing equipment or shrimp that has long been widely known by the majority of Indonesian fishermen. Based on the belief if it violates the abstinence then the results obtained in the payangan will be few. Conservation values contained in the payang system, utilization of natural resources using simple and environmentally friendly equipment can minimize damage to the ecosystem.

\section{REFERENCE}

Aguilar-Stoen, Mariel. 2015. Global forest conservations initiativies as spaces for participation in Colombia and Costa Rica. Journal Geoforum 61 (2015) 36-44.

Amry, R. A., Renta, P. P., \& Nofridiansyah, E. (2017). Analisa Kelayakan Usaha Penangkapan Ikan Menggunakan Alat Tangkap Payang (Seine Net) Menggunakan Alat Bantu Rumpon Di Pantai Malabero Kota Bengkulu. (Analysis of Feasibility of Fishing Business Using Payang Fishing Equipment (Seine Net) Using Rumpon Tools In Malabero Beach, Bengkulu City). Jurnal Enggano, 2(2), 129-142. https://doi.org/10.31186/jenggano.2.2.129-142

Arief, A. (2005). Hutan dan Kehutanan (forests and forestry). Yogyakarta: Kanisius.

Ayatrohaedi. (2016). Kepribadian Budaya Bangsa (Personality of the nation's culture). Jakarta: Pustaka Jaya.

Beltrán J, Phillips A. (2010). Indigenous and traditional peoples and protected areas: principles, guidelines and case studies. Cambridge (UK): IUCN, Cambridge and WWF International. 
Brandt, A.V. (1995). Classification of Fisher Gear, Modern Fishir Gear of The World. Fishing News. Ltd London.

Boesono, W. A. H. (2014). Analisis Efisiensi Teknis Genuine Payang Dan Modifikasi Payang Dengan Windows Samping Terhadap Hasil Tangkapan Di Perairan Kabupaten Kendal (Technical Efficiency Analysis Genuine Payang And Modification Payang With Windows Side To Catch In The Waters of Kendal Regency). Journal of Fisheries Resources Utilization Management and Technology, 3, 46-53.

Bohensky EL, Maru Y. (2011). Indigenous Knowledge, Science, and Resilience: What Have We Learned from a Decade of International Literature on Integration?. Ecology and Society. 16(4): 1-7.

Da Cunha, L. V. F. C., \& De Albuquerque, U. P. (2006). Quantitative ethnobotany in an Atlantic Forest fragment of Northeastern Brazil- Implications to conservation. Environmental Journal Monitoring and Assessment. 114(1-3): 1-25.

Direktorat Jenderal Konservasi Sumberdaya Alam dan Ekosistem (KSDAE). (2016). Statistik Direktorat Jenderal KSDAE (Statistics of the Directorate General of KSDAE). Jakarta: KLHK.

Direktorat Jenderal Perlindungan Hutan dan Konservasi Alam (Ditjen PHKA). (2014). Statistik (statistics) Jakarta: Ditjend PHKA.

Denzin, NK and YS Lincoln (eds). (2000). Handbook of Qualitatif Research, Thousand Oaks, London, New Delhi: Sage Publication.

Fauzi, Hamdani. (2013). Pembangunan Hutan Berbasis Kehutanan Sosial (Social Forestry Based Forest Development). Bandung: Karya Putra Darwanti.

Francis, W. (2015). Keunikan Masyarakat Adat (Uniqueness of indigenous peoples). Yogyakarta: Gadjah Mada University Press.

Fraser DJ, Coon T, Prince MR, Dion R, Bernatchez L. (2006). Integrating Traditional and Evolutionary Knowledge in Biodiversity Conservation: a Population Level Case Study. Journal Ecology and Society. 11(2):1-7.

Freitas DMD, Tagliani PRA. (2009). The Use of GIS for The Integration of Traditional and Scientific Knowledge in a Supporting Artisanal Fisheries Management in Southern Brazil. Journal of Enviromental Management. 90(6):2071-2078.

Gagnon CA, Berteaux D. (2009). Integrating Traditional Ecological Knowledge and Ecological Science: a Question of Scale. Journal Ecology and Society. 14(2):1-8.

Gauthama, M.P, Kusrestuwardhani, Alkadri. (2013). Budaya Jawa dan Masyarakat Modern (Javanese Culture and Modern Society). Jakarta: BPPT Press.

Henri, H., Hakim, L., \& Batoro, J. (2018). Kearifan Lokal Masyarakat sebagai Upaya Konservasi Hutan Pelawan di Kabupaten Bangka Tengah, Bangka Belitung (Local Wisdom of The Community as a Conservation Effort for Pelawan Forest in Central Bangka Regency, Bangka Belitung). Jurnal Ilmu Lingkungan, 16(1), 49. https://doi.org/10.14710/jil.16.1.49-57

Iswandono, Elisa. (2016). Integrasi Kearifan Lokal Masyarakat Suku Manggarai dalam Konservasi Tumbuhan dan Ekosistem Pegunungan Ruteng Nusa Tenggara Timur 


\section{Conservation of Natural Resource Management in the Buffer Village Community of Alas Purwo Banyuwangi National Park East Java Indonesia Based on Local Wisdom Eko Setiawan, Keppi Sukesi, Kliwon Hidayat, Yayuk Yuliati}

(Integration of Local Wisdom of Manggarai People in Plant Conservation and Ecosystem of Ruteng Mountains of East Nusa Tenggara) (Disertasi). Bogor (ID): Institut Pertanian Bogor.

Kosmaryandi N. (2012). Pengembangan Zonasi Taman Nasional: Sintesis Kepentingan Konservasi Keanekaragaman hayati dan Kehidupan Masyarakat Adat (National Park Zoning Development: Synthesis of Biodiversity Conservation Interests and Indigenous Peoples' Lives) (Disertasi). Bogor (ID): Institut Pertanian Bogor.

Liliweri, A. (2014). Pengantar Studi Kebudayaan (Introduction to Cultural Studies). Bandung: Nusamedia

Magdalena. (2013). Peran Hukum Adat Dalam Pengelolaan Dan Perlindungan Hutan Di Desa Sesaot, Nusa Tenggara Barat dan Desa Setulang, Kalimantan Timur (The Role of Customary Law in Forest Management and Protection in Sesaot Village, West Nusa Tenggara and Setulang Village, East Kalimantan). Jurnal Sosial Ekonomi. Vol.10 No.2. doi.org/10.14710/jkt.v19i2.839.

Mangunjaya, Fachruddin M, Husein Heriyanto, Reza Gholami. (2017). Menanam Sebelum Kiamat, Islam, Ekologi, dan Gerakan Lingkungan Hidup (Planting Before The Apocalypse, Islam, Ecology, and the Environmental Movement). Jakarta: Yayasan Obor Indonesia.

Mendez-Lopez. (2014). Local participation in biodiversity conservation initiatives: a comparative analysis of different models in South East Mexico. Journal of Environmental Management 125(1): 321-329.

Moller H, Berkes F, Lyyer PO, Kislalioglu M. (2004). Combining Science and Traditional Ecological Knowledge: Monitoring Populations for Co-Management. Journal Ecology and Society. 9(3):1-10.

Mulyana, Deddy. (2003). Metodologi Penelitian Kualitatif (Qualitative Research Methodology). Bandung: PT Remaja Rosdakarya.

Munggoro, D.W. 1999. Manajemen Kemitraan: Meretas Kemelut Kawasan Konservasi dalam Seminar Pemberdayaan Aset Perekonomian Rakyat Melalui Strategi Kemitraan di Kabupaten Jember (Partnership Management: Hacking Into Conservation Areas in Seminar on Empowering People's Economic Assets Through Partnership Strategy in Jember Regency). Bogor: Pustaka Latin.

Naidoo R, Hill K. (2006). Emergence of Indigenous Vegetation Classifications Through Integration of Traditional Ecological Knowledge and Remote Sensing Analyses. Journal Enviromental Management. 38(3):377-386.

Neuman, William Lawrence. (2003). Social Research Methods: Qualitative and quantitative Approaches. Pearson Education.

Nurdin, B. V., and Ng, K. S. F. (2013). Local Knowledge of Lampung People in Tulang Bawang: An Ethnoecological and Ethnotechnological Study for Utilization and Conservation of Rivers. Procedia - Social Science and Behavioral. 91: 113-119.

Permana, Raden Cecep Eka. (2011). Kearifan Lokal Tentang Mitigasi Bencana Pada Masyarakat Baduy (Local Wisdom on Disaster Mitigation in Baduy Community). Jurnal Makara Sosial Humaniora Vol. 15 No. 1 Juli 2011 Hal 67-76. 
Pramusanti. (2001). Interaksi Masyarakat Sekitar dengan Taman Nasional Alas Purwo (Studi Kasus di Desa Kendalrejo Kecamatan Tegaldimo Kabupaten Banyuwangi Provinsi Jawa Timur) (Interaction of Local Communities with Alas Purwo National Park (Case Study in Kendalrejo Village, Tegaldimo District, Banyuwangi Regency, East Java Province) [Skripsi]. Bogor (ID): Institut Pertanian Bogor.

Primadesi, Y. (2010). Peran Masyarakat Lokal dalam Usaha Pelestarian Naskah-Naskah Kuno Paseban (The Role of Local People in The Conservation of Paseban Ancient Manuscripts). Jurnal Bahasa dan Seni. Vol 11 no (2): 120-127.

Richeri, M., Cardoso, M. B., and Ladio, A. H. (2013). Soluciones Locales y Flexibilidad en el Conocimiento Ecol??Gico Tradicional Frente a Procesos de Cambio Ambiental: Estudios de caso en Patagonia. Journal Ecologia Austral. 23(3): 184-193.

Soemarwoto, Otto. (2014). Ekologi, Lingkungan Hidup dan Pembangunan (Ecology, Environment and Development). Jakarta: Djambatan.

Teng, I. (2017). Bobeto Sebuah Nilai Kearifan Lokal Pembentuk Ruang Ritual antara Manusia dengan Alam di Kalaodi - Tidore (Bobeto A Value of Local Wisdom Forming Ritual Space between Humans and Nature in Kalaodi - Tidore). Local Wisdom: Jurnal Ilmiah Kajian Kearifan Lokal, 9(1), 12-22. https:/ / doi.org/10.26905/lw.v9i1.1863

Thaman. (2016). A comparison of rural comunity perceptions and involvement in conservations between the Fiji Island and Southwestern Portugal. Journal Ocean \& Coastal Management 133 (2016) 43-52.

Triastianti, R. D., Nasirudin, N., Sukirno, S., \& Warsiyah, W. (2018). Konservasi Sumber Daya Air Dan Lingkungan Melaluhi Kearifan Lokal Di Desa Margodadi Kecamatan Seyegan Kabupaten Sleman Yogyakarta (Conservation of Water Resources and Environment Through Local Wisdom in Margodadi Village, Seyegan District, Sleman $\begin{array}{lllll}\text { Regency Yogyakarta). Jurnal } & \text { Kawistara, }\end{array}$ https://doi.org/10.22146/kawistara.15391

Van Assendelf HB. (1991). Waterholes, Mammals and Human Impact in Alas Purwo Baluran National Park East Java Indonesia, An Inventory along the coast in 1991. FONC project, Fakultas Kehutanan Universitas Gajah Mada, Yogyakarta.

Widiana, F., \& Wikantiyoso, R. (2018). Pengembangan Wisata Pantai Sendang Biru Untuk Pelestarian Pulau Sempu. Local Wisdom: Jurnal Ilmiah Kajian Kearifan Lokal (Tourism Development of Blue Sendang Beach for the Preservation of Sempu Island). Jurnal Lokal Wisdom 10(1), 9-17.

Wilkinson, S. (1998). Focus group methodology: a review. International Journal of Social Research Methodology. 1(3): 181-203.

Wikantoyoso, Respati. (2019). Kearifan Lokal Dalam Perencanaan dan Perancangan Kota; Untuk Mewujudkan Arsitektur Kota Berkelanjutan (Local Wisdom in Urban Planning and Design; To Realize Sustainable City Architecture). Malang: Malang Grup Konservasi Arsitektur dan Kota.

Wong, L. P. (2008). Focus group discussion: a tool for health and medical research. International Journal Singapore Medical. 49(3): 256-260.

Yamani, M. (2011). Strategi Perlindungan Hutan Berbasis Hukum Lokal di Eman Komunitas Adat Daerah Bengkulu (Local Law-Based Forest Protection Strategy in 
Conservation of Natural Resource Management in the Buffer Village Community of Alas Purwo Banyuwangi National Park East Java Indonesia Based on Local Wisdom Eko Setiawan, Keppi Sukesi, Kliwon Hidayat, Yayuk Yuliati

Eman Indigenous Communities of Bengkulu Region). Jurnal Hukum No.2 Vol. 18, April 2011. 